\title{
New Normal Digital Marketing (Instagram) Effect on Purchase Intention (Case Study in Wingstop Restaurant)
}

\author{
I Ketut Yasa \\ Politeknik Negeri Bali, Indonesia
}

\begin{abstract}
Digital marketing is the activity of marketing or promoting a brand or product using digital media or the internet. The influence of digital marketing strategies is certainly not far from the use of the internet and social media. Because this one application is often used by people during this new normal era. The increasing number of people who use social media is also being used by business owners, because by using social media as a means to provide information on the latest promos or simply creating content to increase engagement rates. The number of existing social media such as Instagram, Facebook, Twitter etc. One example of a social media platform that is often used by business people is Instagram. The purpose of this study was to determine whether there is any influence from social media marketing Instagram Restaurant Wingstop on purchase intentions at a Wingstop restaurant. This study uses a quantitative mode using premier and secondary data. The data collection technique consisted of observation and questionnaires. The population in this study was 114,000 people who were taken from the number of Instagram followers of the restaurant wingstop, and the sample used in this study was 100 people. For the data analysis process using simple regression analysis, the coefficient of determination with social media marketing as variable $\mathrm{x}$ (independent) and purchase intention as variable $\mathrm{y}$ (dependent). Social media marketing has a significant influence on purchase intention. With a result of 0.187 which implies that the influence of the independent variable (social media marketing) on the dependent variable (purchase intention) is $18.7 \%$, while the remaining $81.3 \%$ is influenced by other factors not examined in this study.
\end{abstract}

Keywords: social media marketing, purchase intention, Instagram

DOI: $10.7176 / \mathrm{EJBM} / 13-21-06$

Publication date: November $30^{\text {th }} 2021$

\section{INTRODUCTION}

Advances in technology make the development of the internet continue to increase, the need for information and knowledge is also a factor in its development (Akmala, 2018). The internet itself is a network that connects computers to each other using the global standard transmission control protocol or internet protocol suite (TCP/IP) as an exchange protocol so that we can interact, communicate and exchange information with each other even over long distances. With the internet, business people are greatly helped because of the new normal of this era. Because recently the government has implemented a new normal era or new habits. According to the Indonesian government, the definition of new normal is a new order to adapt to Covid-19. The purpose of holding this new normal is to move the community's economy again, because the previous one had made the economic sector and experienced a crisis. Even though we can now carry out activities as before, the implementation of the new normal still has to pay attention to various health protocols. The public is still asked to practice physical distancing and reduce activities outside the home. Then the habit of washing hands and using hand sanitizers and also wearing masks must still be observed. Every business owner has made innovations and new breakthroughs to survive in the face of this new normal era. Business owners are able to develop marketing strategies as part of adaptation to survive and thrive in these conditions. One of them is by utilizing digital marketing strategy technology. (Novianita, et al, 2020). Not only in the community, this health protocol must also be practiced by business owners. The goodness of physical distancing and social distancing made by the government can inhibit the transmission of Covid-19 infection where since the emergence of Large-Scale Social Restrictions (PSBB) many companies are thinking about how to reduce direct interaction but still be able to develop business. Implementation of health protocols and efforts that need to be considered to always maintain a healthy lifestyle so that consumers can avoid the dangers of transmission and the impact of health problems from the transmission of the Covid-19 virus. (Ahyar, 2020)

Every business owner has made innovations and new breakthroughs to survive in the face of this new normal era. Business owners are able to develop marketing strategies as part of adaptation to survive and thrive in these conditions. One of them is by utilizing digital marketing strategy technology (Novianita, et al 2020). Digital marketing is the activity of marketing or promoting a brand or product using digital media or the internet. (Didin Hadi Saputra, 2020, p. 1). The purpose of digital marketing is to attract consumers and potential consumers, as we know the acceptance of technology and the internet in society is very broad, so that digital marketing activities are made the main choice in this new normal era. The effect of digital marketing strategies is certainly not far from the use of the internet and social media. Because this one application is often used by people during this new normal era. The increasing number of people who use social media is also used by business owners, because they 
use social media as a means to provide information about the latest promos or just create content to increase engagement rates. The number of existing social media such as Instagram, Facebook, Twitter, etc. One example of a social media platform that is often used by business people is Instagram.

Instagram is an application that has a function to share photos and videos. With easy use, this application is of interest to various groups, both for sharing information related to daily activities and for business purposes. (Sholihah, 2018). Regarding the use of Instagram in business, Instagram can make it easier for entrepreneurs to market and promote their products on the internet. Instagram provides convenience for consumers and producers. With the new normal state of the era like this, business actors can use Instagram for media marketing and promoting their business so that they can reach the wider community. One of the business units using Instagram as a promotional medium is the Wingstop restaurant.

Wingstop is a chicken wings restaurant from the United States which was founded in 1994 in Greenland, Texas, United States. The main dish served by the Wingstop restaurant is fried chicken wings combined with various types of sauces. Wingstop Indonesia has a way of doing business. different from several competing companies in the food and beverage sector. If other companies prioritize speed in serving guests and serving food or fast food, Wingstop prioritizes product quality and taste. Wingstop products are made to order (made fresh to order). That way, guests who visit can enjoy the sensation of hot chicken wings with a choice of 10 different flavors.

With the new normal situation in this era, many consumers are afraid to eat dine-in and also leave the house, therefore social media is considered the most effective media for promotion and can also provide information about the safety of health protocols for consumers who want to dine-in.

One of the marketing strategies carried out by the Wingstop restaurant is the marketing mix, namely price, product, location and promotion. This restaurant really emphasizes its products. By having a variety of flavors provided. The variety of flavors owned by Wingstop restaurant certainly gives its own characteristics to its competitors. For consumers, culinary connoisseurs, of course, it gives a new and very unique impression to buy products from a wingstop restaurant (Maksum \& Satrio, 2018). Wingstop restaurant also uses social media as a means of promotion. One of them uses social media Instagram.

The use of social media as a company business tool offers several advantages for companies. Among them are helping companies improve the company's image by managing good relationships with customers, so as to increase sales and reduce costs to retain customers. Another advantage is that companies can easily interact with customers through intense social media and can also build trust for various services with customers. Having a good relationship with customers is very helpful in buying interest in a company.

H1: Digital Marketing has a positive and significant effect on purchase intention.

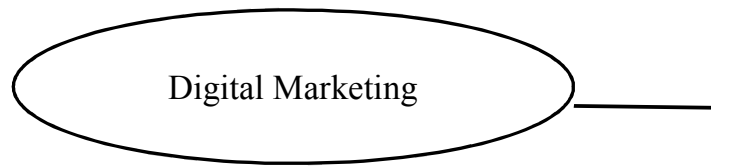

H1

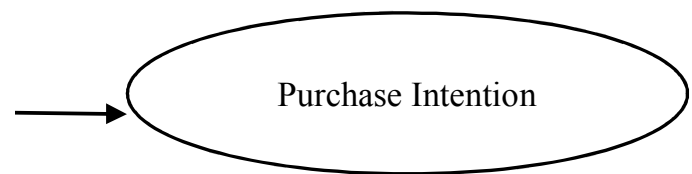

Figure 1. Conceptual Framework

\section{Methods}

This research was conducted at a wingstop restaurant and the subject of this research is the consumers of the wingstop restaurant. This research lasted for approximately 5 months. The research method used in this study is a quantitative method. The variables used in this study are the independent variable, the dependent variable. In this research method, the independent variable is social media marketing and the dependent variable in this research is purchase intention. In this study, the population is the number of Instagram followers from the Wingstop restaurant social media account. With a known number of followers, there are 114,000 followers. In this study the sample technique used is non-probability sampling, with the type used is purposive sampling, namely a sample that includes respondents, subjects or elements selected for certain characteristics or qualities, and ignores those who do not meet the specified criteria. (Morrisan, 2017, p. 117). With the number of samples used for 100 respondents. This study uses premier data types, namely using a questionnaire. The data analysis used is simple regression analysis.

\section{Result and Discussion}

Based on the results of the research above, in this study, there were 100 questionnaires used in testing this study. Judging from the distribution of gender characteristics, the number of female sexes is more dominant than men, then in the distribution of age characteristics, it can be seen that ages 21-24 have the highest number compared to others, and for the distribution of the last educational characteristics, it can be seen in table 4.3 which has similar results. the same between high school / vocational school and also for universities which amounted to $50 \%$ in the distribution of overall characteristics it can be concluded that women aged 21-24 with the last education of high 
school / vocational or university are more likely to buy at Wingstop Restaurants.

Coefficient Determination

Table 1. Coefficient Determination

\begin{tabular}{|l|l|l|l|l|}
\hline Model & R & R Square & Adjusted R Square & Std. Error of the Estimate \\
\hline 1 & $.833^{\mathrm{a}}$ & .887 & .879 & 2.959 \\
\hline
\end{tabular}

Primary Data, 2021

From the output, the coefficient of determination $\left(\mathrm{R}^{2}\right)$ is 0.887 , which implies that the effect of digital marketing on purchase intention is $88.7 \%$, while the remaining $11.3 \%$ is influenced by other factors outside the research model.

Simple Regression Analysis

Table 2. Simple Regression Analysis

\begin{tabular}{|c|c|c|c|c|c|}
\hline \multirow[b]{2}{*}{ Model } & \multicolumn{2}{|c|}{ Unstandardized Coefficients } & \multirow{2}{*}{$\begin{array}{l}\text { Standardized Coefficients } \\
\text { Beta }\end{array}$} & \multirow[b]{2}{*}{$\mathrm{T}$} & \multirow[b]{2}{*}{ Sig. } \\
\hline & $\mathrm{B}$ & Std. Error & & & \\
\hline 1 (Constant) & 11.812 & 1.950 & & 6.056 & .000 \\
\hline Digital Marketing & .325 & .068 & .433 & 4.750 & .000 \\
\hline
\end{tabular}

Primary Data, 2021

The digital marketing coefficient value is 0.325 which means that if social media marketing Instagram has increased by one unit, the purchase intention will increase by 0.325 with a significant value (sig) of 0.00 which has a value less than 0.05 and a $t$ value of 4.750 . > from the $t$ table value of 1.98472 , it can be said that digital marketing has a positive and significant effect on purchase intention.

\section{CONCLUSION}

In the new normal era, the government applies new rules to reduce distance, reduce traveling outside the house. The way to stay afloat in business marketing is to do digital marketing. Digital marketing carried out by Wingstop Restaurant through the promos offered has been proven to positively and significantly influence consumers' purchase intentions. Based on the coefficient of determination test as much as $88.7 \%$ digital marketing affects consumers' purchase intentions. Although government regulations seem to narrow business opportunities, it is time for business people to follow this digitalization era so that they are not left behind by other competitors.

\section{References}

Ahyar, A. K. (2020). PENGARUH PHYSICAL DISTANCING DAN SOCIAL DISTANCINGTERHADAP KESEHATAN DALAM PENDEKATAN LINGUISTIK. Jurnal Syntax Transformation, 18.

Akmala, S. (2018). PERKEMBANGAN INTERNET PADA GENERASI MUDA DI INDONESIA DI INDONESIA DENGAN KAITAN UNDANG-UNDANG ITE YANG BERLAKU. CyberSecurity dan Forensik Digital, 45.

Alfianika, N. (2018). Buku Ajar Metode Penelitian Pengajaran Bahasa Indonesia. Deepublish.

Alfonsius. (2020). PELAYANAN TRANSPORTASI ONLINE DI ERA NEW. Journal of Accounting \& Management Innovation, Vol.4 No.2, 2020, pp. 76-90, 93.

Amiruddin, S. M. (2019). PENGARUH ETOS KERJA, DISIPLIN DAN MOTIVASI TERHADAP KINERJA PEGAWAI PADA DINAS PERINDUSTRIAN DAN PERDAGANGAN KABUPATEN BIAK NUMFOR. Penerbit Qiara Media.

Maksum, M., \& Satrio, R. B. (2018). ENGARUH HARGA, PRODUK, LOKASI DAN PROMOSI TERHADAP KEPUTUSAN PEMBELIAN PADA RESTORAN WINGSTOP. Jurnal Ilmu dan Riset Manajemen, 2.

Morrisan, M. d. (2017). Metode Penelitian Survei. Kencana.

Novianita , R., Nur Fitri Rahmawati, \& Dewi Nurbaiti. (2020). Strategi Komunikasi Pemasaran Usaha Mikro Kecil Dan Menengah Pada Era New Normal. Prosiding Seminar Stiami, 25.

sholihah, a. (2018). penggunaan instagram sebagai media promosi (studi deskriptif pada product teh Thailand pikameame di Yogyakarta. 2.

Sholihah, a. (2018). penggunaan instagram sebagai media promosi (studi deskriptif pada product teh Thailand pikameame di Yogyakarta. 2. 